Trismadi Pranata, Dasman Lanin, Adil Mubarak|Pelaksanaan Kualitas Pelayanan Kesehatan di Puskesmas Sitiung Kecamatan Sitiung Kabupaten Dharmasraya

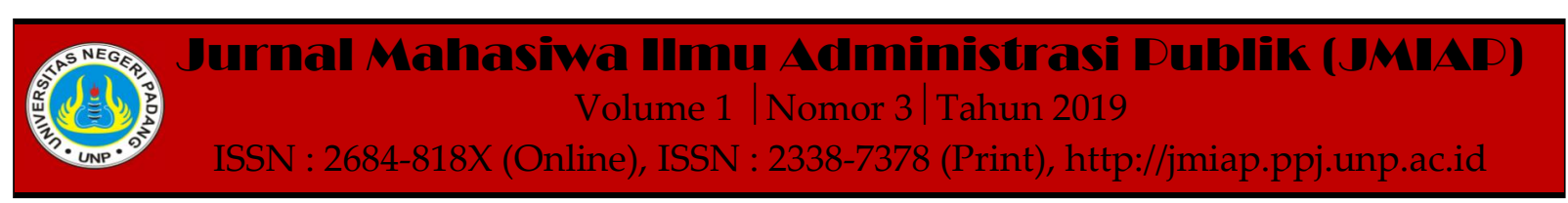

\title{
PELAKSANAAN KUALITAS PELAYANAN KESEHATAN DI PUSKESMAS SITIUNG KECAMATAN SITIUNG KABUPATEN DHARMASRAYA
}

\author{
Trismadi Pranata ${ }^{1(a)}$, Dasman Lanin ${ }^{2(b)}$, Adil Mubarak ${ }^{3(c)}$ \\ ${ }^{1}$ Jurusan Ilmu Administrasi Negara, Universitas Negeri Padang \\ ${ }^{2}$ Jurusan Ilmu Administrasi Negara, Universitas Negeri Padang \\ ${ }^{3}$ Jurusan Ilmu Administrasi Negara, Universitas Negeri Padang \\ a)trismadipranata@yahoo.co.id, ${ }^{b}$ dasmanlain@gmail.com, ${ }^{c}$ adilmubarak08@yahoo.co.id
}

\begin{abstract}
This study aims to determine the quality of health services in the Sitiung Health Center, Sitiung District, Dhasrmasraya Regency. This research is a descriptive study. Data collection techniques are done by observation, interview, and documentation. The research informants in this study were people who had been treated at the Sitiung Health Center, Sitiung District, Dharmasraya Regency.From the results of the study showed that the implementation of the quality of health services in the Sitiung Health Center, Sitiung District, Dhasrmasraya Regency viewed from aspects of tangible, reliability, responsiveness, assurance, empathy, empathy, namely: (empathy), namely: (1) Physical Evidence Indicators (Tangibles) in the good percentage category so that the quality of health services at the Sitiung Community Health Center, Sitiung District, Dharmasraya Regency viewed from the Physical Evidence indicator (Tangibles) are judged to be of high quality. (2) Reliability Indicators are also in the good percentage category so that the quality of health services at the Sitiung Health Center, Sitiung District, Dharmasraya Regency in terms of the Reliability indicators is considered to be of quality. (3) Responsiveness Indicator in the percentage category is good so that the quality of health services at the Sitiung Community Health Center, Sitiung District, Dharmasraya Regency is seen from the Responsiveness indicator as being considered to be of good quality. because medical personnel have received and served well and take action according to procedure. (4) Guarantee indicator (Ansurance) is in the good percentage category so that the quality of health services at the Sitiung Community Health Center, Sitiung District, Dharmasraya Regency can be seen from the quality guarantee (Ansurance). (5) Empathy Indicator (Emphaty) in the good percentage category so that the quality of health services at the Sitiung Community Health Center, Sitiung District, Dharmasraya Regency is seen from the Empathy (Emphaty) dimension of quality.
\end{abstract}

Keywords : Quality of Health services at Sitiung Health Center, Sitiung District, Dharmasraya District Corresponding author. Email. trismadipranata@yahoo.co.id, dasmanlain@gmail.com, adilmubarak08@yahoo.co.id

How to cite this article. Pranata. T, Lanin. D \& Mubarak. A. (2019). Pelaksanaan Kualitas Pelayanan Kesehatan di Puskesmas Sitiung Kecamatan Sitiung Kabupaten Dharmasraya. Jurnal Mahasiwa Ilmu Administrasi Publik (JMIAP) Jurusan Ilmu Administrasi Negara Fakultas Ilmu Sosial Universitas Negeri Padang, Volume 1 (3), Hal. 51-55.

http://jmiap.ppj.unp.ac.id

ISSN : 2684-818X (Online), ISSN : 2338-7378 (Print)

Copyright@2019. Published by Pusat Kajian-Pemberdayaan dan Pelayanan Masyarakat (PK-P2M) FIS UNP Padang 


\section{PENDAHULUAN}

Pemerintah mempunyai tanggung jawab diberbagai bidang. Salah satu tanggung jawab pemerintah adalah di bidang pelayanan publik namun dilaksanakan oleh instansi pemerintah pusat maupun pemerintah daerah. Pelayanan dibidang kesehatan adalah bentuk dari pelayanan publik.Reformasi di bidang kesehatan ini dilakukan bertujuan untuk meningkatkan pelayanan di bidang kesehatan agar menjadi lebih efisien dan efektif.

Dalam kehidupan sehari-hari, pelayanan tidak bisa dipisahkan dengan manusia, karena dalam melangsungkan kehidupannya manusia selalu membutuhkan pelayanan. Kualitas pelayanan rumah sakit termasuk Puskesmas, dapat diketahui dari profesionalitas personil rumah sakit itu sendiri dan dapat dilihat dari kepuasan pasien atas layanan yang diberikan oleh rumah sakit atau puskesmas. Menurut Yamit (dalam Aldri dan Dede, 2014) kualitas pelayanan adalah ukuran penilaian menyeluruh antara harapan konsumen dan sistem kerja cara pelayanan yang baik.

Menurut Parasuraman, (dalam Agung Budiono, 2014), ada lima dimensi dalam pelayanan jasa yang disebut dengan Service Quality, diantaranya :

1) Bukti fisik (tangibles), tangibles berkaitan dengan fisik seperti fasiltas yang dapat dirasakan langsung oleh seseorang.

2) Kehandalan (reliability), kehandalan lebih ke profesionalitas, dimana dapat memberikan pelayanan dengan baik dan tepat waktu.

3) Daya tanggap (responsiveness), yaitu berkaitan dengan kesigapan karyawan dalam memberikan layanan.

4) Jaminan (assurance), jaminan beraitan dengan rasa aman pasien terhadap dan kepercayaan pasien bahwa pegawai di puskesmas benarbenar berkompeten.
5) Empati (emphaty), empati adalah rasa kepedulian terhadap pasien dan memberikan kemudahan kepada pasien untuk menghubungi pegawai jika dibutuhkan.

Kelima dimensi mutu pelayanan diatas sangat penting, karena apabila semuanya terpenuhi maka mutu playanan di puskesmas akan tergolong baik. Karena dengan kualitas pelayanan, kita dapat mengetahui apakah pasien puas dengan pelayanan di puskesmas Sitiung, Kecamatan Sitiung, Kabupaten Dharmasraya.

Oleh karena itu penelitian ini bertujuan Untuk mengetahui pelaksanaan kualitas pelayanan kesehatandi Puskesmas Sitiung, Kecamatan Sitiung, Kabupaten Dharmasraya.

\section{TINJAUAN PUSTAKA}

\section{Konsep Pelayanan}

Menurut UU No.25 Tahun 2009 tentang Pelayanan Publik, Pelayanan publik adalah kegiatan atau rangkaian kegiatan dalam rangka pemenuhan kebutuhan pelayanan sesuai dengan peraturan perundangundangan bagi setiap warga negara dan penduduk atas barang, jasa, dan/atau pelayanan administratif yang disediakan oleh penyelenggara pelayanan publik. Pelaksana pelayanan publik yang selanjutnya disebut Pelaksana adalah pejabat, pegawai, petugas, dan setiap orang yang bekerja di dalam organisasi penyelenggara yang bertugas melaksanakan tindakan atau serangkaian tindakan pelayanan publik.

\section{Konsep pelayanan kesehatan}

Menurut Notoadmodjo (dalam Soleh Iskandar, 2016) Pelayanan Kesehatan adalah upaya kesehatan adalah setiap kegiatan untuk memelihara dan meningkatkan kesehatan yang dilakukan oleh pemerintah atau masyarakat. Sejalan dengan hal tersebut, berdasarkan UU RI No. 36 Tahun 2009 pasal 1 ayat 11 pengertian 
upaya atau pelayanan kesehatan adalah "setiap kegiatan dan/atau serangkaian kegiatan yang dilakukan secara terpadu, terintegrasi dan berkesinambungan untuk memelihara dan meningkatkan derajat kesehatan, pengobatan penyakit, dan pemulihan kesehatan oleh pemerintah dan/atau masyarakat.

Parasuraman, (dalam Agung Budiono, 2014), menganalisis Dimensi mutu jasa berdasarkan lima aspek komponen mutu. Lima aspek komponen mutu pelayanan dikenal dengan nama Servqual (Service Quality). Dimensi mutu menurut Parasuraman dkk terdiri dari lima dimensi, yaitu :

1) Bukti fisik (tangibles), mutu pelayanan dapat dirasakan langsung terhadap penampilan fasilitas fisik serta pendukung pendukung dalam pelayanan.

2) Kehandalan (reliability), yaitu kemampuan untuk memberikan tepat waktu dan akurat sesuai dengan yang ditetapkan.

3) Daya tanggap (responsiveness), yaitu kesediaan petugas untuk memberikan pelayanan yang cepat sesuai prosedur dan mampu memenuhi harapan pelanggan.

4) Jaminan (assurance), yaitu berhubungan dengan rasa aman dan kenyamanan pasien karena adanya kepercayaan terhadap petugas yang memiliki kompetensi, kredibilitas dan ketrampilan yang tepat dalam memberikan pelayanan dan pasien memperoleh jaminan pelayanan yang aman dan nyaman.

5) Empati (emphaty), yaitu berhubungan dengan kepedulian dan perhatian petugas kepada setiap pelanggan dengan mendengarkan keluhan dan memahami kebutuhan serta memberikan kemudahan bagi seluruh pelanggan dalam menghubungi petugas.

\section{METODE PENELITIAN}

Penelitian ini dilaksanakan di Puskesmas Sitiung, Kecamatan Sitiung, Kabupaten Dhasrmasraya. Penelitian menggunakan penelitian kuantitatif dengan metode deskriptif. disini penulis akan mendeskripsikan bagaimana kualitas pelayanan kesehatan di puskesmas Sitiung, kecamatan Sitiung, kabupaten Dharmasraya. Cara menentukan Sampel dalam penelitian ini adalah dengan cara Random Sampling.

Dalam mengumpulkan data penulis membagikan kuisioner kepada sampel penelitian dan studi dokumentasi. Teknik analisis data dalam penelitian ini adalah menggunakan analisis deskriptif kuantitatif.

\section{HASIL DAN PEMBAHASAN}

Masalah pelayanan pada sektor publik sampai saat ini masih menjadi pokok pembicaraan yang menarik, terlebih di era pelaksanaan otonomi daerah. Muncul asumsi bahwa dengan otonomi daerah kinerja pelayanan publik akan semakin baik karena jarak pemerintah dan rakyat yang dilayani sudah semakin dekat. Asumsi itu menjadi mentah ketika begitu banyak persoalan pelayanan di sektor publik terungkap, terutama terkait dengan aspek perbaikan kinerja atau prestasi (performance) pelayanan public(Dasman Lanin \& Adil Mubarak, 2010)

\section{Pelaksanaan Kualitas Pelayanan Kesehatan Di Puskesmas Sitiung, Kecamatan Sitiung, Kabupaten Dharmasraya.}

Tangibles (Bukti Fisik)dari Puskesmas terlihat sangat tertata rapi dan bersih serta memiliki ruang tunggu yang nyaman. Puskesmas Sitiung memiliki peralatanperalatan medis yang lengkap, serta tenaga medis yang selalu berpenampilan bersih dan rapi.

Iindikator Reliability (Kehandalan) maka dapat dikatakan bahwa Reliability (Kehandalan) di puskesmas Sitiung dapat dikatakan baik karena tenaga medis 
selalumelayani pasien dengan teliti. Tenaga medis selau hati-hati dalm memberikan pelayanan kepad pasien dan tenaga medis membantu jika terjadi permasalahan, tenaga medis memberikan pertolongan secara cepat serta pelayanan yang diberikan sesuai dengan harapan dan sesuai dengan yang diharapkan.

Responsiveness (Daya Tanggap) dapat dikatakan baik, karena tenaga medis menerima dan melayani dengan baik, tenaga medis melakukan tindakan sesuai prosedur, tenaga medis selalu menanyakan keluhan yang dirasakan pasien, mempunyai tenaga medis yang siap melayani 24 jam serta tenaga medis memberikan kesempatan kepada pasien untuk bertanya.

Indikator Assurance (jaminan) dapat dikatakan baik karena tenaga medis menyediakan peralatan dan obat-obatan yang lengkap.Puskesmas Sitiung memiliki Dokter yang terdidik dan ahli pada bidangnya sehingga meyakinkan pasien serta membuat pasien merasa aman dan terjamin.

Dari indikator Emphaty (empati) dapat dikatakan baik, karena terlihat dari rata-rata rekapitulasi empati sebesar 74,67\%. Emphaty (empati) dari tenaga medis memperhatikan pasien secara sungguhsungguh, tenaga medis mampu untuk memenuhi kebutuhan pasien, tenaga medis dan dokter berusaha untuk menenangkan pasien terhadap penyakit yang diderita, memberikan waktu yang cukup untuk pasien berkonsultasi dengan dokter dan tenaga medis dan tenaga medis memberikan pelayanan sesuai dengan keinginan pasien.

\section{PENUTUP}

Berdasarkan hasil penelitian, maka dapat disimpulkan bahwa :

1. Indikator Bukti fisik (Tangibles) dalam kategori persentase baik sehingga kualitas pelayanan kesehatan Puskesmas Sitiung, Kecamatan Sitiung, Kabupaten
Dharmasraya dilihat dari indikator Bukti Fisik (Tangibles) dinilai sudah berkualitas.

2. Indikator Kehandalan (Reliability) juga berada pada kategori persentase baik sehingga kualitas pelayanan kesehatan Puskesmas Sitiung, Kecamatan Sitiung, Kabupaten Dharmasraya dilihat dari indikator Keandalan (Reliability) dinilai sudah berkualitas. Tenaga medis memberikan pelayanan dengan teliti serta dengan hati-hati pelayanan ini dinilai sudah baik, tenaga medis juga membantu jika terjadi permasalahan dan memberikan pertolongan secara cepat kesiapan tenaga medis sesuai dengan harapan pasien.

3. IndikatorDaya Tanggap (Responsiveness) dalam kategori persentase baik sehingga kualitas pelayanan kesehatan Puskesmas Sitiung, Kecamatan Sitiung, Kabupaten Dharmasraya dilihat dari indikator Daya Tanggap (Responsiveness) dinilai sudah berkualitas. karena tenaga medis sudah menerima dan melayani denga baik serta melakukan tindakan sesuai prosedur. Tindakan segera petugas dalam menyelesaikan masalah dan memberikan informasi yang mudah dimengerti juga mendapat respon yang baik dari masyarakat. Tenaga medis juga siap melayani selama 24 jam dan memberikan kesempatan kepada pasien untuk bertanya keluhan penyakit yang dirasakan.

4. Indikator Jaminan (Ansurance) berada pada kategori persentase baik sehingga kualitas pelayanan kesehatan Puskesmas Sitiung, Kecamatan Sitiung, Kabupaten Dharmasraya dilihat dari indikator Jaminan (Ansurance) dinilai sudah berkualitas. Keseluruhan indikator Jaminan (Ansurance) sudah baik dengan kata lain pelayanan sudah 
berkualitas. Karena Tenaga medis sudah meyediakan peralatan dan obat-obatan yang lengkap untuk pasien, dan memiliki dokter yang ahli pada bidangnya,sehingga meyakinkan pasien serta membuat pasien merasa aman dan terjamin.

5. Indikator Empati (Emphaty) dalam kategori persentase baik sehingga kualitas pelayanan kesehatan Puskesmas Sitiung, Kecamatan Sitiung, Kabupaten Dharmasraya dilihat dari dimensi Empati (Emphaty) sudah berkualitas. Perhatian tenaga mediskepada pasien memberikan kesan yang baik kepada pasien, sikap adil dan tidak membeda-bedakan, tenaga medis mampu memenuhi kebutuhan pasienserta berusaha untuk menenangkan pasien terhadap penyakit yang dideritadan memberikan pelayanan sesuai dengan keinginan pasien ini mendapatkan respon yang baik dari pasien.

6. Dilihat dari hasil penelitian diketahui bahwa kualitas pelayanan kesehatan di PuskesmasSitiung, Kecamatan Sitiung, Kabupaten Dharmasraya semuanya sudah berada pada kategori baik (berkualitas) maka disimpulkan bahwa pelayanan kesehatan Puskesmas Puskesmas Sitiung, Kecamatan Sitiung, Kabupaten Dharmasraya berkualitas.

\section{DAFTAR KEPUSTAKAAN}

Arikunto, Suharsimi. (2014). Prosedur Penelitian Suatu Pendekatan Praktik. Jakarta: Rineka Cipta.

Bungin, Burhan. (2005). Metode Penelitian Kuantitatif: Komunikasi Ekonomi dan Kebijakan Publik Serta Ilmu-Ilmu Sosial Lainnya. Jakarta: Gramedia Pustaka.
Dasman Lanin, \& Adil Mubarak. (2010). Kepuasan Diskonfirmasi Warga pada Sektor Publik: Kasus Pelayanan Kebutuhan Dasar Pemerintahan Kota Padangpanjang. Jurnal Demokrasi, Vol.9 No.2 2010. http://ejournal.unp.ac.id/index.php/jd/articl e/view/1420/1230.

Sugiyono. (2013). Cara Mudah Menyusun Skripsi, Tesis, Dan Dosertasi. Yogyakarta:. Alfabeta.

Sugiyono. (2014). Mettode Penelitian Kuantitatif, Kualitatif dan $R$ dan $D$. Bandung: Alfabeta. 